Article

\title{
New Nitro-Laterally Substituted Azomethine Derivatives; Synthesis, Mesomorphic and Computational Characterizations
}

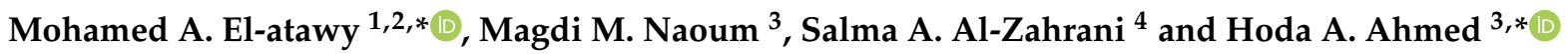 \\ 1 Chemistry Department, Faculty of Science, Alexandria University, P.O. 426 Ibrahemia, \\ Alexandria 21321, Egypt \\ 2 Chemistry Department, Faculty of Science, Taibah University, Yanbu 46423, Saudi Arabia \\ 3 Department of Chemistry, Faculty of Science, Cairo University, Cairo 12613, Egypt; \\ magdinaoum@yahoo.co.uk \\ 4 Department of Chemistry, College of Sciences, University of Ha'il, Ha'il 2440, Saudi Arabia; \\ s.alzahrane@uoh.edu.sa \\ * Correspondence: mohamed.elatawi@alexu.edu.eg (M.A.E.-a.); ahoda@sci.cu.edu.eg (H.A.A.)
}

check for updates

Citation: El-atawy, M.A.; Naoum, M.M.; Al-Zahrani, S.A.; Ahmed, H.A. New Nitro-Laterally Substituted Azomethine Derivatives; Synthesis, Mesomorphic and Computational Characterizations. Molecules 2021, 26, 1927. https://doi.org/10.3390/ molecules26071927

Academic Editor: Alexander V. Aksenov

Received: 25 February 2021

Accepted: 23 March 2021

Published: 30 March 2021

Publisher's Note: MDPI stays neutral with regard to jurisdictional claims in published maps and institutional affiliations.

Copyright: (c) 2021 by the authors. Licensee MDPI, Basel, Switzerland. This article is an open access article distributed under the terms and conditions of the Creative Commons Attribution (CC BY) license (https:// creativecommons.org/licenses/by/ $4.0 /)$.

\begin{abstract}
Two new homologues series, based on two rings of the azomethine central group bearing the terminal alkoxy group of various chain lengths, were prepared. The alkoxy chain length varied between 6 and 16 carbons. The other terminal wing in the first series was the $\mathrm{F}$ atom, and the compound is named N-4-florobenzylidene-4-(alkoxy)benzenamine ( $\mathbf{I} n)$. The second group of compounds included a lateral $\mathrm{NO}_{2}$ substituent in addition to the terminal $\mathrm{F}$ atom, named $\mathrm{N}$-(4-fluoro3-nitrobenzylidene)-4-(alkyloxy)aniline (II $n$ ). Mesomorphic and optical properties were carried out via differential scanning calorimetry (DSC) and polarized optical microscopy (POM). Elemental analyses, FT-IR, and NMR spectroscopy were carried out to elucidate the molecular structures of the synthesized groups. Mesomorphic investigations indicated that all the synthesized homologues (In) were monomorphic, possessing the smectic A (SmA) phase monotropically, while the second group (II $n)$ members were non-mesomorphic. The experimental data indicated that the formation of the mesophase is affected by the protrusion of the lateral nitro group. The disruption of the mesophase in the second group was attributed to the increase of its molecular width, which affects its lateral intermolecular interactions. The computational simulations were in agreement with the experimental data. On the other hand, the location of $\mathrm{NO}_{2}$ group within the molecular geometry increased the melting temperature of the molecule, and thus, affected their thermal and physical properties. By discussing the estimated parameters, it was found that the molecular architecture, the dipole moment, and the polarizability of the investigated compounds are highly affected by the electronic nature and position of the terminal and lateral substituents as well as their volumes.
\end{abstract}

Keywords: lateral nitro-substituent; azomethine liquid crystals; mesophase stability; geometrical structure; DFT

\section{Introduction}

Today, liquid crystalline (LC) materials prove to have wide area of technological applications as optical displays, emitting-diodes, and photoconductors based on organic compounds [1-3]. Geometric characteristic relationships are important tools to synthesize a suitable structural shape to achieve the desired properties for specific industrial applications [4-7]. Molecular shape enables some considerable modifications in the mesomorphic properties and plays an important role in the formation, kind, and thermal stability of the produced mesophase [8-15]. In addition, the choices of the laterally attached groups, terminal wings, as well as the mesogenic linkages are important criteria in the formation of thermotropic LC for proper characteristic applications.

The $\mathrm{NO}_{2}$ group is one of the most important substituents of organic derivatives [16-18]. The incorporation of a nitro substituent into a molecular structure significantly increases 
the electronegativity of the molecule [17-24]. The strong mesomeric property of the $\mathrm{NO}_{2}$ moiety induces a positive charge on the $\mathrm{N}$ atom, and thus, increases the electronegativity of the group $[17,18]$. The resonance approach has been supported by dipole moment investigations [25], NMR, and the chemical electron-withdrawing character of the nitro group, which affects the measurements [26-28]. For the development of the mesomorphic range and mesophase stabilities of the prepared materials, an effective strategy for modification of the architectures of compounds is necessary. Therefore, the insertion of a compact lateral and terminal group into the calamitic thermotropic liquid crystals [29] is important. Generally, adjusting the type and size of terminal substituents can offer good changes in mesophase behavior [30,31]. In addition, a small change of the terminal lengths or electronic nature of groups can alter the terminal and parallel interactions [13,15].

Schiff base linkages have been broadly employed in the preparation of numerous LC derivatives [32-36]. Most reports have been focused on Schiff bases since the discovery of nematogenic 4-methoxybenzylidene-4'- butylaniline at room temperature [37]. Recently, several thermotropic Schiff base liquid crystals based on two rings were documented [32,38-47].

Simulations of the theoretical calculations for predicting the molecular geometry are more interesting for the estimation of the thermal properties, and we correlated them with the experimental findings data $[8,9,48-52]$.

The aim of the present investigation is to synthesize new di- and tri-substituted azomethine liquid crystals based on two benzene rings (Scheme 1). Moreover, we also aimed to investigate the effect of the introduction of lateral nitro-substituents to the linear structure of a terminally substituted fluorine molecule, the effect on the mesomorphic, and the optical behavior of the synthesized architectures. Furthermore, geometrical parameters estimated from density functional theory (DFT) calculations of different sizes of attached substituents were correlated to explain the outcome of the experimental results.<smiles>OCCCCOc1ccc(/N=C/c2ccc(F)cc2)cc1</smiles>

In $\mathrm{n}=6,8$, and 16

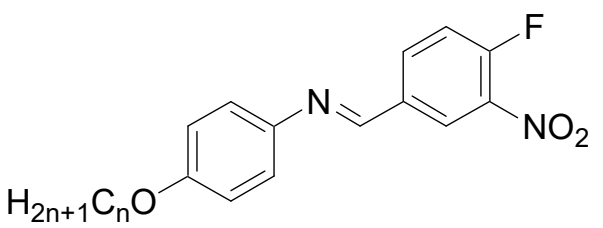

IIn

Scheme 1. Synthesized groups I $n$ and II $n$.

\section{Results and Discussion}

\subsection{Mesomorphic and Optical Behavior}

The transition temperatures of the synthesized groups N-4-florobenzylidene-4(alkoxy)benzenamine (In ) and N-(4-fluoro-3-nitrobenzylidene)-4-(alkyloxy)aniline (II $n$ ), as well as their associated enthalpies, were derived from differential scanning calorimetry (DSC) measurements, and are summarized in Table 1. The mesophases were identified via polarized optical microscopy (POM). DSC thermograms are illustrated in Figure 1 upon the heating/cooling for the I 8 and II16 derivatives, taken as examples. The POM images showed a focal-conic fan texture for the smectic A (SmA) phase for group I $n$ upon cooling (Figure 2). In order to ensure the thermal stabilities of the investigated derivatives, DSC measurements were performed for second heating scans. In addition, DSC evaluations were confirmed by the POM image observations. In order to investigate the effect of the terminal alkoxy chain groups on the mesomorphic properties of synthesized groups, the relationship of the graphical transition temperatures DSC data was illustrated and is shown in Figure 3. Members of the nitro-free, terminal fluoro-substituted homologues (group I $n$ ) exhibited only one transition peak upon heating and two transition peaks on the cooling cy- 
cles, as indicated by their DSC thermograms, which were assigned to Cr-to-isotropic liquid phase (during heating) in addition to the SmA-to-Cr phase (upon cooling). On the other hand, all compounds of di-substituted $\mathrm{F}$ and $\mathrm{NO}_{2}$ moieties exhibited only one transition peak upon the heating and cooling scans, which was assigned to the Cr-to-isotropic liquid mesophase. These data were consistent with the POM investigations. Table 1 and Figure 3 reveal that the laterally neat $\mathrm{NO}_{2}$ homologues, $\mathbf{I} n$, only possessed the smectic A phase monotropically. Moreover, there was, as usual, no regular change of melting temperatures with the increase of the terminal alkoxy chain length $(n)$. It was previously reported that the position of the lateral $\mathrm{NO}_{2}$ group within the molecular structure also increases the melting transition temperature [28]. Their SmA stability and range also increases gradually with $n$. The homologue with the shortest alkoxy chain (I6) exhibited the lowest thermal smectic stability at $66.9^{\circ} \mathrm{C}$ with a smectogenic temperature range of $5.4^{\circ} \mathrm{C}[32,53]$. The higher homologue $\mathrm{I} 16$ possessed smectogenic stability at $76.3^{\circ} \mathrm{C}$ and temperature range of more than $56.3^{\circ} \mathrm{C}$ (see Supplementary Materials). The small size of the F atom enables its introduction into mesomorphic structures without any steric disruption, and consequently, LCs mesophases can still be observed. The high polarity also serves to enhance the optical morphology, transition phenomena, and other physical parameters. Additionally, the polar terminal $\mathrm{F}$ changes the polarizability and the dipole moment of the whole molecular structure to an extent, depending on its location and orientation in the molecule. This was reflected on the mesophase and optical behaviors of the investigated molecule. The insertion of lateral nitro group near the $\mathrm{F}$ atom in the molecule is associated with a little change in the molecular shape, but changes do exist in the polarity and orientation of the dipole moments. The mesomorphic measurements revealed that, all the homologues of group II $n$ that were laterally $\mathrm{NO}_{2}$-substituted proved to be non-mesomorphic. This may be attributed to the large volume of the nitro group and the high-molecular packing that not only disrupts the SmA mesophase, but also prevents the formation of any mesophase. It was documented [54] that the type of phase and its stability are mainly dependent on the dipole moment of the mesogenic part of the molecule, which varies according to the incorporated polar groups and its steric effect, which changes with the volume and location of the substituent.

Table 1. Phase transition temperatures $\left({ }^{\circ} \mathrm{C}\right)$, enthalpy of transition $\Delta \mathrm{H}, \mathrm{kJ} / \mathrm{mole}$, and mesophase temperature range, $\Delta \mathrm{T}$, for groups $\mathrm{N}$-4-florobenzylidene-4-(alkoxy)benzenamine (In) and N-(4-fluoro3-nitrobenzylidene)-4-(alkyloxy)aniline (II $n)$.

\begin{tabular}{|c|c|c|c|c|c|c|c|}
\hline \multirow{2}{*}{$\begin{array}{l}\text { Cycle } \\
\text { Comp. }\end{array}$} & \multicolumn{2}{|c|}{ Upon Heating } & \multicolumn{4}{|c|}{ Upon Cooling } & \multirow[b]{2}{*}{$\Delta T$} \\
\hline & $T_{\text {Cr-I }}$ & $\Delta H_{\mathrm{Cr}-\mathrm{I}}$ & $T_{\text {I-SmA }}$ & $\Delta H_{\mathrm{I}-\mathrm{SmA}}$ & $T_{\text {SmA-Cr }}$ & $\Delta H_{\mathrm{SmA}-\mathrm{Cr}}$ & \\
\hline I6 & 84.2 & 35.64 & 66.9 & 2.15 & 61.5 & 27.6 & 5.4 \\
\hline I 8 & 88.2 & 39.35 & 71.0 & 2.05 & 54.7 & 32.4 & 16.3 \\
\hline I16 & 79.1 & 36.72 & 76.3 & 1.98 & $<20.0$ & - & $>56.3$ \\
\hline II 6 & 98.2 & 40.74 & - & - & - & - & - \\
\hline II 8 & 88.7 & 38.27 & - & - & - & - & - \\
\hline II16 & 74.8 & 50.61 & - & - & - & - & - \\
\hline
\end{tabular}

Cr-to-isotropic liquid phase (Cr-I) denotes transition from solid to the isotropic mesophase; I-smectic A (I-SmA) denotes transition from isotropic mesophase to the SmA mesophase; SmA-Cr denotes transition from SmA to the solid phase. 

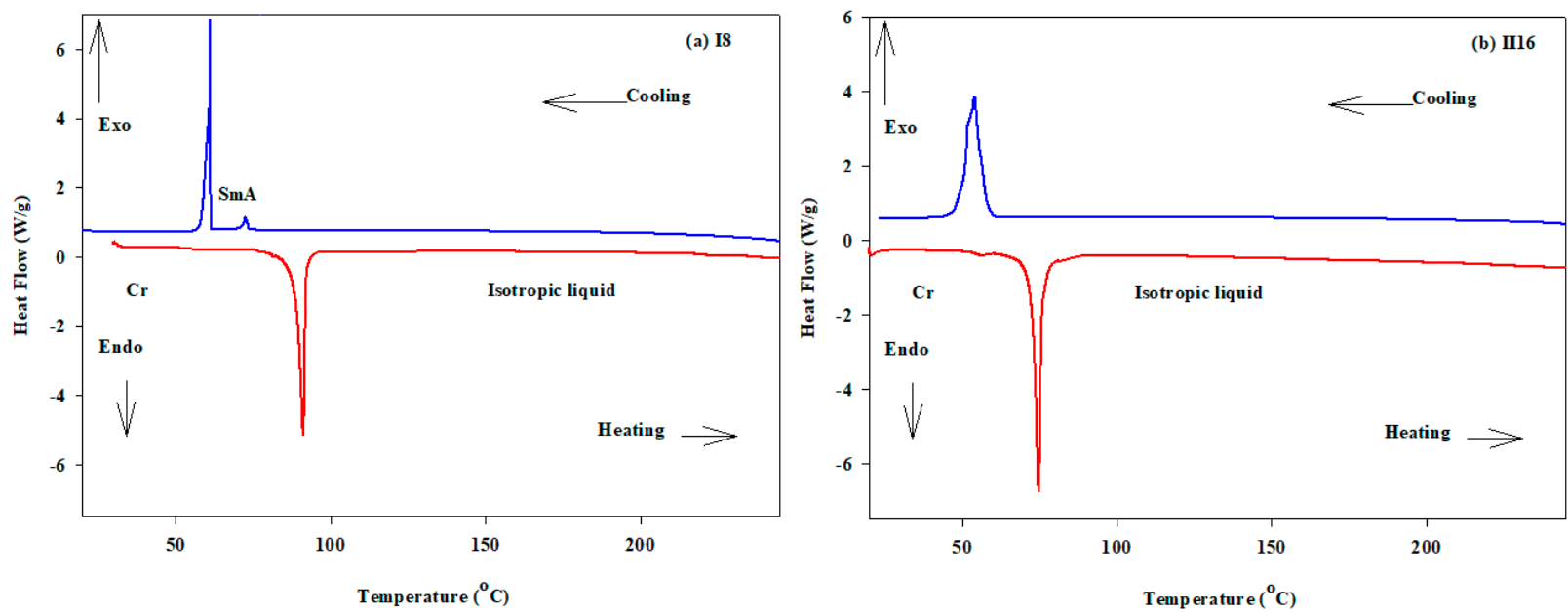

Figure 1. Differential scanning calorimetry (DSC) thermograms of $\mathbf{I} 8$ and III6 derivatives upon the second heating/cooling scan with a rate of $10^{\circ} \mathrm{C} / \mathrm{min}$.

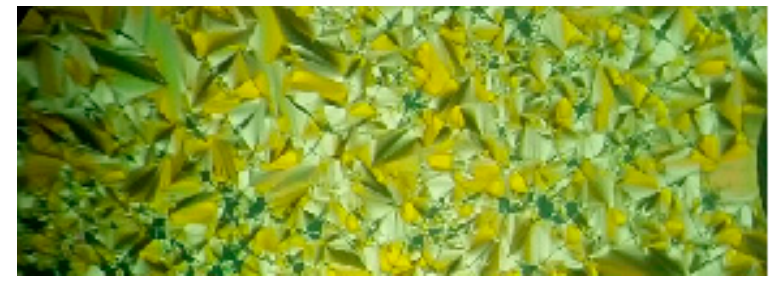

Figure 2. Polarized optical microscopy (POM) texture of SmA phase upon cooling of compound I 8 at $80.0^{\circ} \mathrm{C}$, as an example.
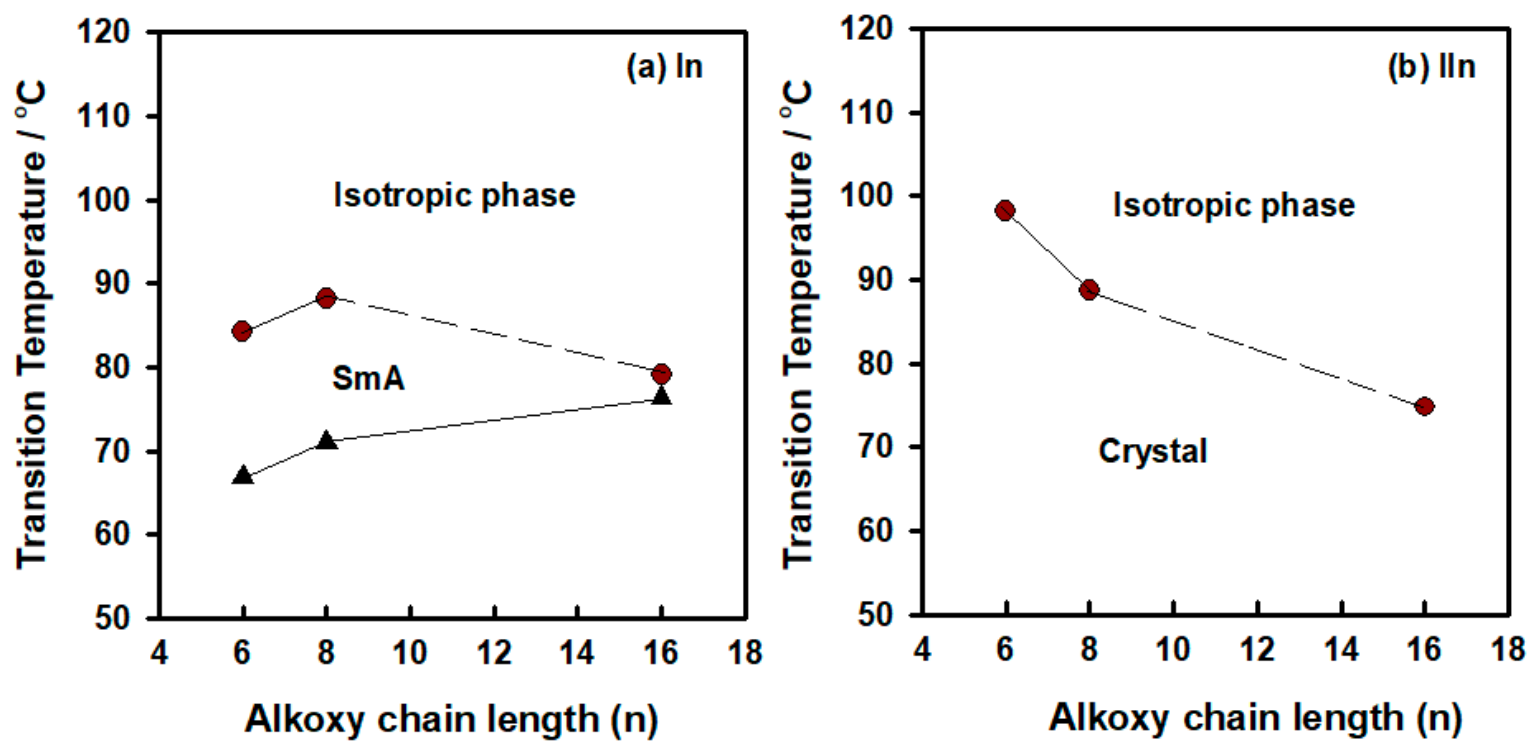

Figure 3. DSC transitions of synthesized groups (a) I $n$ and (b) II $n$; the smectic A mesophase for series I $n$ was observed monotropically (upon cooling).

\subsection{DFT Calculations}

\subsubsection{Geometrical Simulations and Thermal Parameters}

In order to study the effect of mono- and di-substituted compact polar groups on the mesomorphic properties of two-ring azomethine liquid crystals homologues, computational calculations for each of the investigated groups were studied. The estimations were established between the quantum chemical parameters, calculated by DFT theoretical 
calculations, and the experimental findings for the synthesized groups I $n$ and II $n$. Calculations were estimated in the gas phase at the B3LYP level using 6-311 $G^{* *}$ as the basis set of predicted the optimum and stable molecular geometries. All computational calculations are performed by Gaussian 09W package [55]. The results revealed that all homologues exhibited a linear structural shape with planar geometry. In addition, the length of the terminal alkoxy chain $(n)$ and the introduction of the polar $\mathrm{NO}_{2}$ substituent into the molecular skeleton highly affected the structural geometry of the molecule (Figure 4).

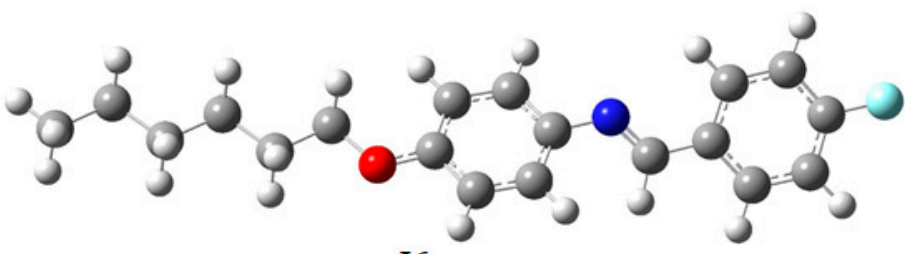

I6

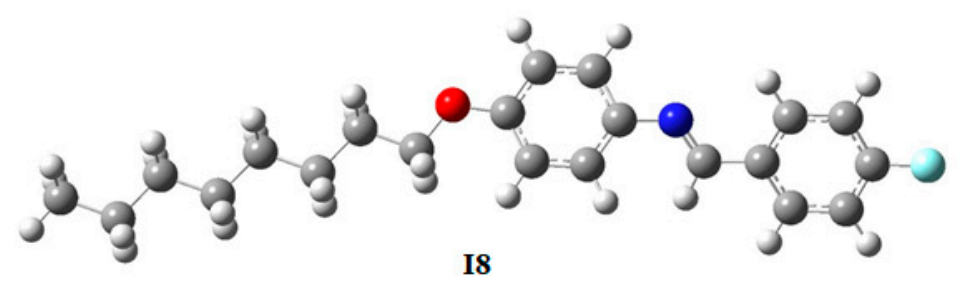

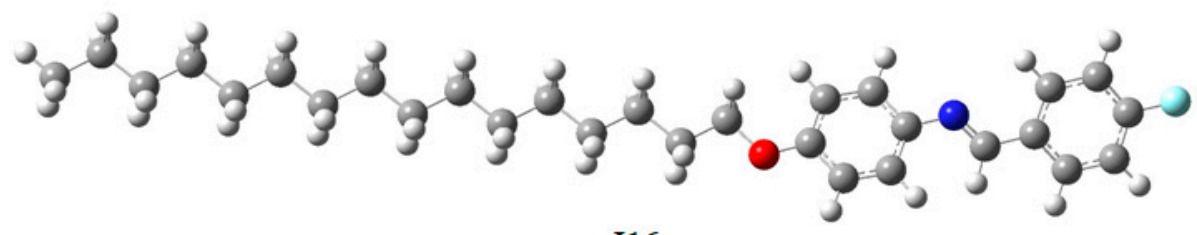

I16

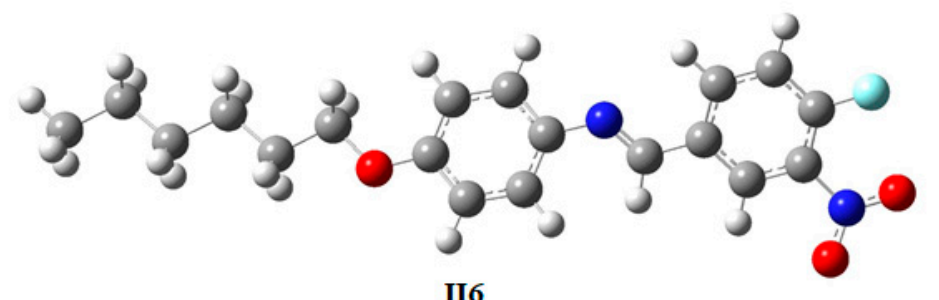

II6

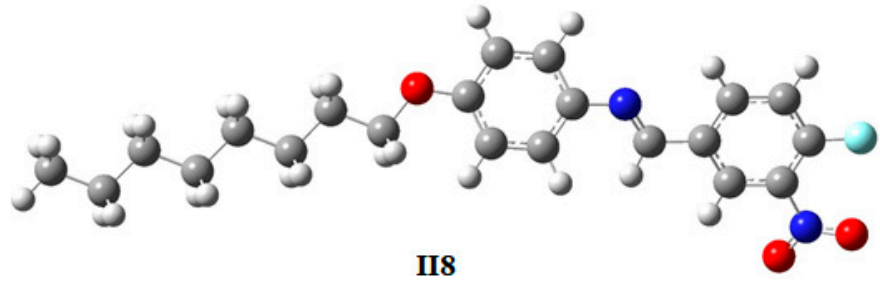

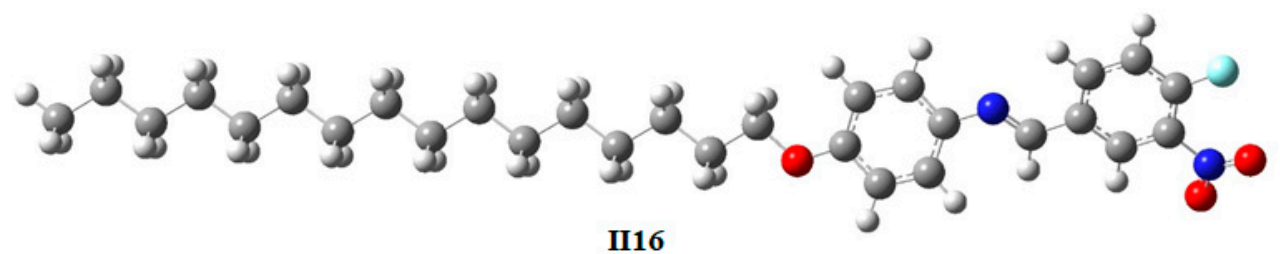

Figure 4. Optimized structures of molecules of the investigated homologues series $\mathrm{I} n$ and II $n$, calculated at the B3LYP/6$311 \mathrm{G}^{* *}$ level. 
The thermal energy, enthalpy, Gibb's free energy, and entropy, as well as the total energy of the synthesized groups at room temperature, were calculated at the B3LYP/6311G (d, p) level and collected, as shown in Table 2. Moreover, other predicted geometrical parameter values are summarized in Table 3. The data in Tables 2 and 3 show that the thermal and geometrical parameters, which were predicted from DFT calculations, were highly affected by the electronic nature of the lateral substituent $\left(\mathrm{NO}_{2}\right)$. The aspect ratio, polarity, polarizability, rigidity of the cores, and the architecture shape of the individual molecules, as well as the attached polar groups, were essential parameters to affect the type and thermal stability of the observed mesophase [12], in addition to the competition between the intermolecular lateral and terminal interactions, all impacted the mesomorphic characteristics of the resulting molecules. The dipole moment of the whole molecules was highly affected by the electronic nature and position of the polar substituents $\left(\mathrm{F}\right.$ and $\left.\mathrm{NO}_{2}\right)$. The laterally $\mathrm{NO}_{2}$-substituted group (II $n$ ) exhibited the highest dipole moment compared to the laterally neat first group $(\mathbf{I} n)$. Their dipole moment values changed because of the inclusion of the lateral $\mathrm{NO}_{2}$ group, from 3.4343 to 8.3129 Debye for I6 and II6, respectively, from 3.2523 to 7.2100 Debye for I 8 and II 8 , respectively, and from 3.5361 to 8.3918 Debye for I16 and II16, respectively. The data of the estimated dipole moment illustrate the nonmesomorphic properties of group II $n$. The high dipole moment resulted from the highest lateral electron-withdrawing $\mathrm{NO}_{2}$ group, which could make a high lateral interference that opposed the arrangement of molecules, thus preventing mesophase formation. Further, the high electronegativity of the terminal F substituent enhanced the SmA-phase formation in group $\mathrm{I} n$. Moreover, the large volume of the $\mathrm{NO}_{2}$ group leads to steric hindrance, and thus, disrupts the molecular packing of molecules. In Table 3, the ionization energy and electron affinity, calculated as I.E = - E HOMO and E.A = - E EUMO, respectively, are included [56]. Their calculated values almost were not affected by the increment of the alkoxy chain length $(n)$ in either group.

Table 2. DFT calculated thermal parameters using B3LYP/6-311G** method.

\begin{tabular}{|c|c|c|c|c|c|c|}
\hline Compound & $\begin{array}{c}\text { ZPE } \\
\text { (Kcal/Mol) }\end{array}$ & $\begin{array}{c}\text { Thermal } \\
\text { Energy } \\
\text { (Kcal/Mol) }\end{array}$ & $\begin{array}{l}\text { Enthalpy } \\
\text { (Kcal/Mol) }\end{array}$ & $\begin{array}{c}\text { Gibbs Free } \\
\text { Energy } \\
\text { (Kcal/Mol) }\end{array}$ & $\begin{array}{c}\text { Entropy } \\
\text { (Cal mol.k) }\end{array}$ & $\begin{array}{c}\text { Total Energy } \\
\text { (Hartree) }\end{array}$ \\
\hline I6 & 232.110 & 245.514 & 246.107 & 198.082 & 161.077 & -966.673 \\
\hline II6 & 233.080 & 248.147 & 248.739 & 196.560 & 175.010 & -1171.136 \\
\hline I 8 & 268.005 & 283.060 & 283.652 & 231.671 & 174.347 & -1045.237 \\
\hline II 8 & 268.850 & 285.632 & 286.224 & 229.633 & 189.806 & -1249.700 \\
\hline I16 & 411.206 & 433.130 & 433.723 & 364.161 & 233.314 & -1359.495 \\
\hline II16 & 412.130 & 435.744 & 436.336 & 362.232 & 248.547 & -1563.957 \\
\hline
\end{tabular}

Table 3. $\mathrm{E}_{\mathrm{HOMO}}, \mathrm{E}_{\mathrm{LUMO}}, \Delta \mathrm{E}$, the dipole moment, and the polarizability calculated using B3LYP/6-311G $\mathrm{G}^{* *}$ method for the present groups $\mathbf{I} n$ and $\mathbf{I I} n$.

\begin{tabular}{|c|c|c|c|c|c|c|c|}
\hline Compound & $\begin{array}{c}\mathrm{E}_{\text {HOMO }} \\
(\mathrm{ev})\end{array}$ & $\begin{array}{c}\text { EluMo }_{(\mathrm{ev})} \\
\text { (ev) }\end{array}$ & $\begin{array}{c}\Delta \mathrm{E} \\
(\mathrm{ev})\end{array}$ & $\begin{array}{c}\mathrm{IE} \\
(\mathrm{ev})\end{array}$ & $\begin{array}{c}\text { EA } \\
(\mathrm{ev})\end{array}$ & $\begin{array}{l}\text { Dipole Moment } \\
\text { (Debye) }\end{array}$ & $\begin{array}{l}\text { Polarizability } \\
\quad\left(\text { Bohr }^{3}\right)\end{array}$ \\
\hline $\mathbf{I} 6$ & -5.820 & -1.871 & 3.949 & 5.820 & 1.871 & 3.4343 & 253.23 \\
\hline II 6 & -6.185 & -3.207 & 2.978 & 6.185 & 3.207 & 8.3129 & 277.41 \\
\hline I 8 & -5.826 & -1.878 & 3.948 & 5.826 & 1.878 & 3.2523 & 275.53 \\
\hline II 8 & -6.178 & -3.224 & 2.954 & 6.178 & 3.224 & 7.2100 & 299.49 \\
\hline I16 & -5.822 & -1.872 & 3.950 & 5.822 & 1.872 & 3.5361 & 372.25 \\
\hline II16 & -6.177 & -3.207 & 2.970 & 6.177 & 3.207 & 8.3918 & 396.18 \\
\hline
\end{tabular}

The polarizability is another factor $[54,57,58]$ that affects the phase transitions. Table 3 shows that the calculated polarizability increased as the length of terminal alkoxy chain increased for both investigated groups I $n$ and II $n$. On the other hand, the introduction of polarizable group affects the dipole moment and the polarizability of the molecule, 
and accordingly enhances the intermolecular attraction between molecules and the bulk terminal group, facilitating molecular space-filling between the terminal moieties [5].

\subsubsection{Frontier Molecular Orbitals (FMOs)}

Optical studies of non-linear optical (NLO) materials are highly affected by the energy difference between the FMOs, highest occupied molecular orbital (HOMO), and lowest unoccupied molecular orbital (LUMO) [56,59,60]. Figure 5 represents the estimated groundstate density surface plots for the FMOs of the investigated groups $\mathbf{I} n$ and $\mathbf{I I} n$. Table 3 shows the collected results of the FMO energy gaps. As shown in Table 3 and Figure 5, the electron densities of the sites that contributed to the formation of the HOMOs and the LUMOs were localized on each of the azomethine linkage and polar substituent $F$ and $\mathrm{NO}_{2}$ groups. Moreover, the energy gap of FMOs is slightly dependent on the length of alkoxy chain $(n)$. Furthermore, the mesomorphic properties of the calamitic mesogens develop the molecular-molecular interactions that essentially depend on the geometry of the compounds, the polarizability of the terminal and lateral polar substituents, as well as the stereo electronic properties of the whole molecule.

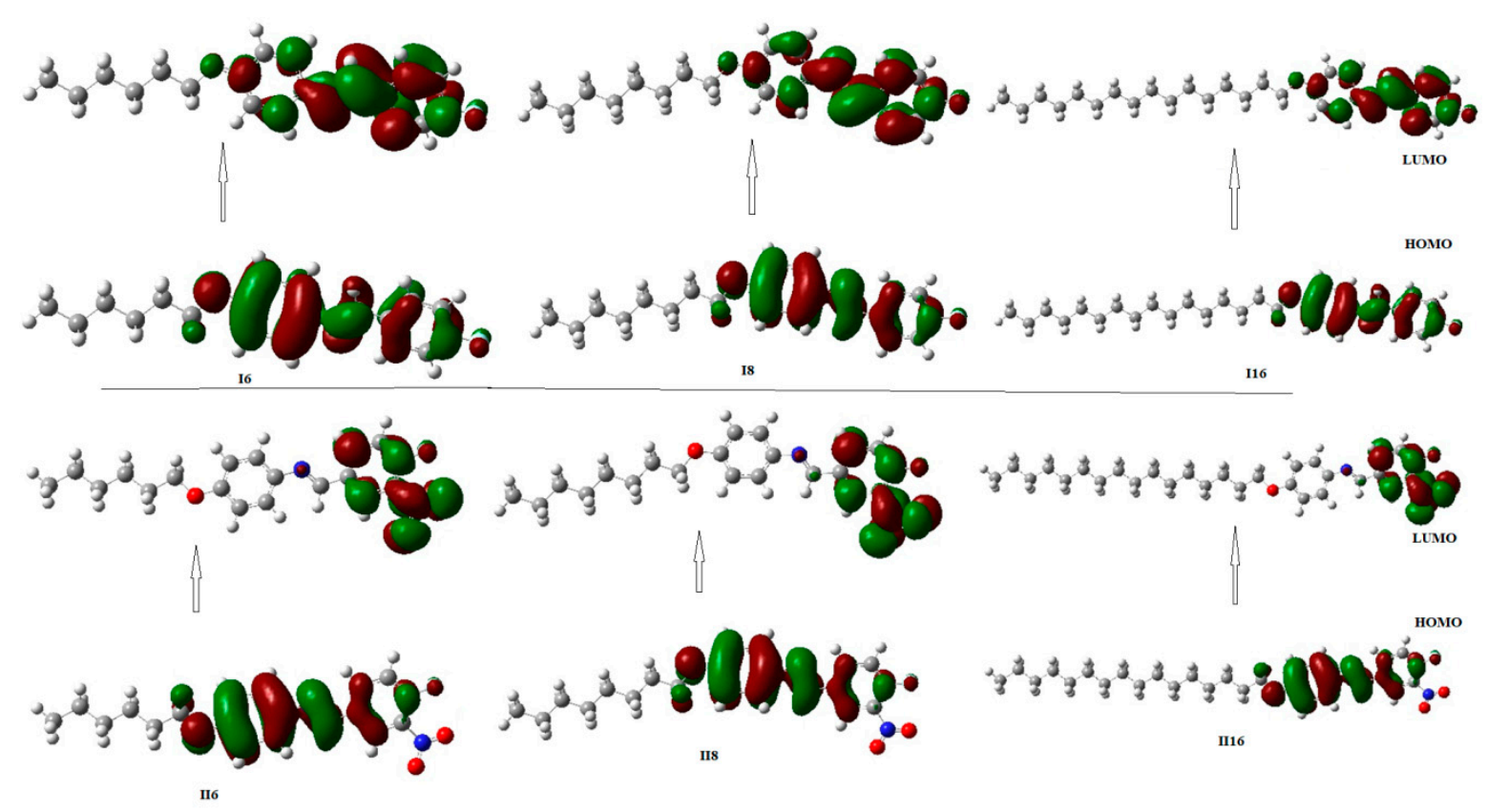

Figure 5. Estimated geometry for frontier molecular orbitals (FMOs) of the investigated groups, I $n$ and II $n$.

\subsubsection{Molecular Electrostatic Potential (MEP)}

Charge distribution maps for the present investigated series, I $n$ and II $n$, were estimated under the same basis sets according to the molecular electrostatic potential (MEP, Figure 6). For group I $n$, the negatively charged atomic sites (red regions) were localized on the oxygen atoms and the terminal $\mathrm{F}$, as well as the nitrogen atom of the azomethine linkage. In the second group (lateral $\mathrm{NO}_{2}$ series), the red regions of negatively charged atomic sites were highly localized on the two oxygen of the lateral $\mathrm{NO}_{2}$ group, on terminal $\mathrm{F}$, and on the nitrogen atom of the azomethine moiety. The alkyl chains in both groups showed the least negatively charged atomic sites (blue regions). As shown in Figure 6, the electronic nature of the terminal and lateral polar substituents, their size, as well as the conformation of the attached group, were more effective on the orientation of the charge distribution map; this could effect the type and thermal stability of the mesophase by altering the competitive interaction between end-to-end and side-to-side interaction. The correlation between the estimated theoretical charge distribution and the mesomorphic properties measurements was recently documented $[8,12,61]$. The alteration of the charge distribution on the whole molecules, because of the mesomeric interactions, enhanced the 
terminal aggregation to induce the $\mathrm{N}$ mesophase, while the parallel interaction induced the smectic A mesophase. Furthermore, the wide separation of the charges, as in case of the steric hindrance in the lateral $\mathrm{NO}_{2}$ group in the homologues of series II $n$, prevented the mesophase formation, i.e., the insertion of the lateral nitro moiety disrupted the SmA phase and resulted in non-mesomorphic analogues. This can be explained in terms of the increased conjugation between the nitro group and azomethine linking moiety, which might increase the molecular non-planarity and non-linearity or attribute to the reduction of intermolecular interactions due to the broadening of the molecules.

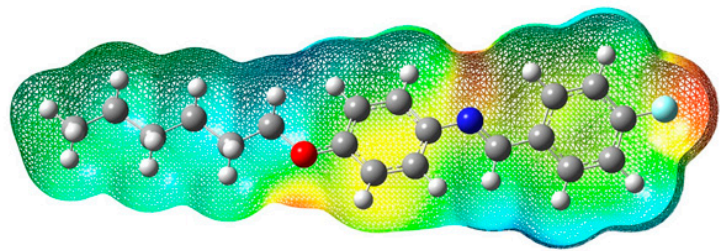

I6
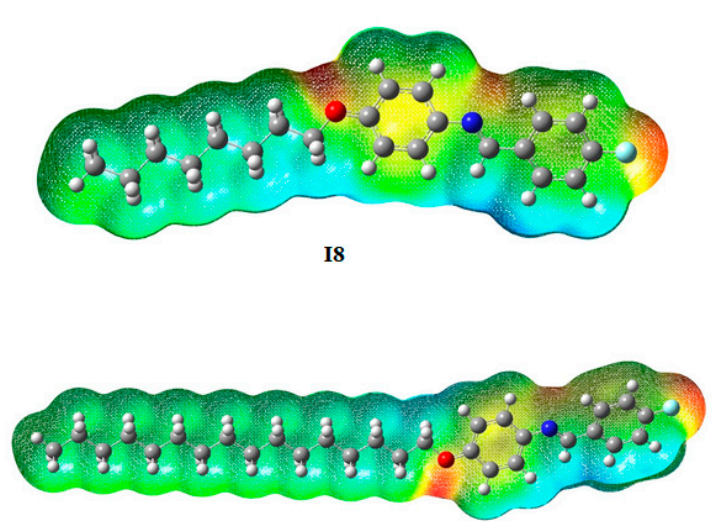

I16

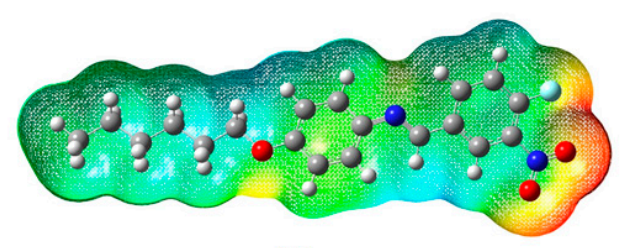

II6

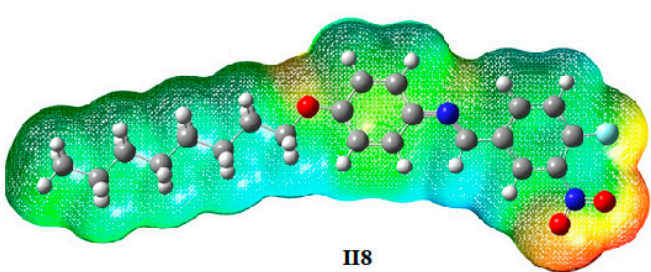

II8

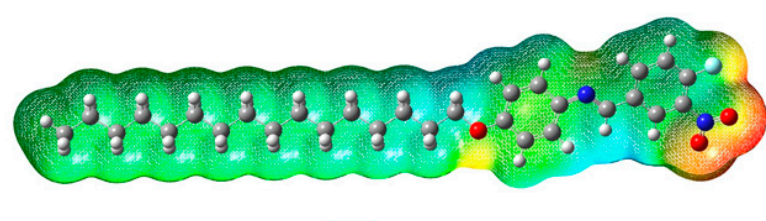

II16

Figure 6. Molecular electrostatic potentials (MEP) of groups I $n$ and II $n$.

\section{Experimental}

\subsection{Materials}

4-hexyloxyaniline, 4-(octyloxy)aniline, 4-(hexadecyloxy)aniline, 4-fluorobenzaldehyde, nitric acid, sulfuric acid and ethanol were purchased from Sigma Aldrich (Germany).

\subsection{Synthesis}

The investigated compounds I $n$ and II $n$ were synthesized according to the following scheme (Scheme 2) and see Supplementary Materials:

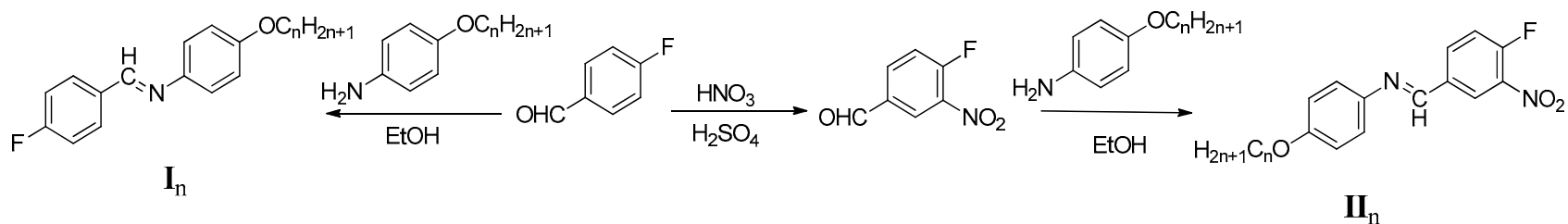

Scheme 2. Synthesis of N-4-florobenzylidene-4-(alkoxy)benzenamine (In) and N-(4-fluoro-3-nitrobenzylidene)-4(alkyloxy)aniline (II $n$ ).

\section{N-4-fluorobenzylidene-4-(hexyloxy)benzenamine, I6}

Yield: $97.0 \%$; mp $84.0^{\circ} \mathrm{C}$, FT-IR $\left(\hat{v}, \mathrm{~cm}^{-1}\right)$ : 2930, $2850\left(\mathrm{CH}_{2}\right.$ stretching), $1630(\mathrm{C}=\mathrm{N})$, $1560\left(\mathrm{NO}_{2}\right), 1365\left(\mathrm{NO}_{2}\right) .{ }^{1} \mathrm{H}$ NMR $\left(500 \mathrm{MHz}, \mathrm{CDCl}_{3}\right) \delta 10.01(\mathrm{~s}, 1 \mathrm{H}), 8.47(\mathrm{~s}, 1 \mathrm{H}), 7.92$ $(\mathrm{d}, J=8.0 \mathrm{~Hz}, 1 \mathrm{H}), 7.85(\mathrm{~d}, \mathrm{~J}=7.7 \mathrm{~Hz}, 1 \mathrm{H}), 7.54(\mathrm{~d}, J=7.9 \mathrm{~Hz}, 1 \mathrm{H}), 7.45\left(\mathrm{dd}, J^{\mathrm{H}-\mathrm{F}}=12.8\right.$, $\left.J^{\mathrm{H}-\mathrm{H}}=8.4 \mathrm{~Hz}, 1 \mathrm{H}\right), 7.31(\mathrm{~d}, J=8.0 \mathrm{~Hz}, 1 \mathrm{H}), 7.25-7.13(\mathrm{~m}, 1 \mathrm{H}), 7.03-6.83(\mathrm{~m}, 1 \mathrm{H}), 4.00$ 
$(\mathrm{t}, J=6.5 \mathrm{~Hz}, 2 \mathrm{H}), 3.95(\mathrm{t}, J=6.3 \mathrm{~Hz}, 2 \mathrm{H}), 1.80-1.71(\mathrm{~m}, 2 \mathrm{H}), 1.41-1.36(\mathrm{~m}, 4 \mathrm{H}), 0.93(\mathrm{t}$, $J=6.2 \mathrm{~Hz}, 3 \mathrm{H}) .{ }^{13} \mathrm{C} \mathrm{NMR}\left(126 \mathrm{MHz}, \mathrm{CDCl}_{3}\right) \delta 190.93,159.21,157.17,151.60,141.14,134.21$, $130.95,129.49,129.17,125.17,124.18,122.32,115.61,115.08,68.33,31.61,29.25,25.65,22.60$, 14.06. Elemental analyses: Found (calculated): C, 76.21 (76.22); H, 7.40 (7.41); N, 4.65 (4.68).

\section{N-4-fluorobenzylidene-4-(octyloxy)benzenamine, I8}

Yield: $93.0 \%$; $\operatorname{mp~} 88.0^{\circ} \mathrm{C}$, FT-IR $\left(\dot{v}, \mathrm{~cm}^{-1}\right)$ : 2935, $2862\left(\mathrm{CH}_{2}\right.$ stretching $), 1632(\mathrm{C}=\mathrm{N})$, $1550\left(\mathrm{NO}_{2}\right), 1362\left(\mathrm{NO}_{2}\right) .{ }^{1} \mathrm{H} \mathrm{NMR}\left(500 \mathrm{MHz}, \mathrm{CDCl}_{3}\right) \delta 8.66(\mathrm{~s}, 1 \mathrm{H}, \mathrm{CH}=\mathrm{N}), 7.89(\mathrm{~d}, 1 \mathrm{H})$, $7.86(\mathrm{~d}, 1 \mathrm{H}), 7.52(\mathrm{~d}, 1 \mathrm{H}), 7.43(\mathrm{dd}, 1 \mathrm{H}), 7.27(\mathrm{~d}, 1 \mathrm{H}), 7.25-7.22(\mathrm{~m}, 1 \mathrm{H}), 7.03-6.99(\mathrm{~m}, 2 \mathrm{H})$, $4.05\left(\mathrm{t}, 2 \mathrm{H}, \mathrm{OCH}_{2}\right), 1.78-1.71\left(\mathrm{~m}, 2 \mathrm{H}, \mathrm{CH}_{2}\right), 1.43-1.30\left(\mathrm{~m}, 10 \mathrm{H}, 5 \mathrm{CH}_{2}\right), 0.89\left(\mathrm{t}, 3 \mathrm{H}, \mathrm{CH}_{3}\right)$. Elemental analyses: Found (calculated): C, 77.03 (76.89); H, 8.00 (7.92); N, 4.28 (4.18).

N-4-fluorobenzylidene-4-(hexadecyloxy)benzenamine, I16

Yield: $95.0 \%$; mp $79.0^{\circ} \mathrm{C}$, FT-IR $\left(v, \mathrm{~cm}^{-1}\right): 2932,2854\left(\mathrm{CH}_{2}\right.$ stretching), $1625(\mathrm{C}=\mathrm{N})$, $1555\left(\mathrm{NO}_{2}\right), 1365\left(\mathrm{NO}_{2}\right) .{ }^{1} \mathrm{H} \mathrm{NMR}\left(500 \mathrm{MHz}, \mathrm{CDCl}_{3}\right) \delta 8.65(\mathrm{~s}, 1 \mathrm{H}, \mathrm{CH}=\mathrm{N}), 7.90(\mathrm{~d}, 1 \mathrm{H})$, $7.83(\mathrm{~d}, 1 \mathrm{H}), 7.55(\mathrm{~d}, 1 \mathrm{H}), 7.45(\mathrm{~m}, 1 \mathrm{H}), 7.29(\mathrm{~d}, 1 \mathrm{H}), 7.20-7.15(\mathrm{~m}, 1 \mathrm{H}), 7.03-6.80(\mathrm{~m}, 2 \mathrm{H})$, $4.06\left(\mathrm{t}, 2 \mathrm{H}, \mathrm{OCH}_{2}\right), 1.77-1.70\left(\mathrm{~m}, 2 \mathrm{H}, \mathrm{CH}_{2}\right), 1.43-1.31\left(\mathrm{~m}, 26 \mathrm{H}, 13 \mathrm{CH}_{2}\right), 0.91\left(\mathrm{t}, 3 \mathrm{H}, \mathrm{CH}_{3}\right)$. Elemental analyses: Found (calculated): C, 79.22 (79.21); H, 9.63 (9.47); N, 3.19 (3.25).

N-(4-fluoro-3-nitrobenzylidene)-4-(hexyloxy)aniline, II6

Yield: $95.1 \%$; $\operatorname{mp} 98.0^{\circ} \mathrm{C}$, FT-IR $\left(v, \mathrm{~cm}^{-1}\right)$ : 2928, $2845\left(\mathrm{CH}_{2}\right.$ stretching), $1610(\mathrm{C}=\mathrm{N})$, $1555\left(\mathrm{NO}_{2}\right), 1360\left(\mathrm{NO}_{2}\right) .{ }^{1} \mathrm{H} \mathrm{NMR}\left(500 \mathrm{MHz}, \mathrm{CDCl}_{3}\right) \delta 8.55(\mathrm{t}, J=7.1 \mathrm{~Hz}, 1 \mathrm{H}, \mathrm{Ar}-\mathrm{H})$, $8.49(\mathrm{~m}, 1 \mathrm{H}, \mathrm{Ar}-\mathrm{H}), 8.19(\mathrm{~s}, 1 \mathrm{H}, \mathrm{CH}=\mathrm{N}), 7.38(\mathrm{~m}, 1 \mathrm{H}, \mathrm{Ar}-\mathrm{H}), 7.26(\mathrm{~m}, 1 \mathrm{H}, \mathrm{Ar}-\mathrm{H}), 6.93(\mathrm{t}$, $J=8.3 \mathrm{~Hz}, 1 \mathrm{H}, \mathrm{Ar}-\mathrm{H}), 4.04-3.91\left(\mathrm{~m}, 2 \mathrm{H}, \mathrm{OCH}_{2}\right), 1.79\left(\mathrm{~d}, J=5.8 \mathrm{~Hz}, 2 \mathrm{H}, \mathrm{CH}_{2}\right), 1.47(\mathrm{~s}, 2 \mathrm{H}$, $\left.\mathrm{CH}_{2}\right), 1.38-1.29\left(\mathrm{~m}, 4 \mathrm{H}, 2 \mathrm{CH}_{2}\right), 0.94-0.88\left(\mathrm{~m}, 3 \mathrm{H}, \mathrm{CH}_{3}\right) .{ }^{13} \mathrm{C} \mathrm{NMR}\left(126 \mathrm{MHz} \mathrm{CDCl}_{3}\right) \delta$ $188.87(\mathrm{C}), 158.81(\mathrm{C}), 156.68\left(\mathrm{~d},{ }^{1} J_{\mathrm{C}, F}=269.2 \mathrm{~Hz}, \mathrm{CF}\right), 153.20(\mathrm{CH}) 134.50\left(\mathrm{~d},{ }^{2} J_{\mathrm{C}, \mathrm{F}}=24.1\right.$ $\mathrm{Hz}, \mathrm{CH}), 127.38\left(\mathrm{~d},{ }^{2} J_{\mathrm{C}, \mathrm{F}}=29.5 \mathrm{~Hz}, \mathrm{C}\right), 119.05\left(\mathrm{~d},{ }^{3} J_{\mathrm{C}, \mathrm{F}}=21.6 \mathrm{~Hz}, \mathrm{CH}\right), 126.07(\mathrm{CH}), 122.56$ $(\mathrm{CH}), 122.28(\mathrm{C}), 115.18(\mathrm{CH}), 68.11\left(\mathrm{OCH}_{2}\right), 31.51\left(\mathrm{CH}_{2}\right), 29.18\left(\mathrm{CH}_{2}\right), 25.83\left(\mathrm{CH}_{2}\right), 22.51$ $\left(\mathrm{CH}_{2}\right), 14.01\left(\mathrm{CH}_{3}\right)$. Elemental analyses: Found (calculated): C, 66.24 (66.26); H, 6.14 (6.15); $\mathrm{N}, 8.10$ (8.13).

N-(4-fluoro-3-nitrobenzylidene)-4-(octyloxy)aniline, II 8

Yield: 93.7\%; mp $89.0^{\circ} \mathrm{C}$, FT-IR (v, $\left.\mathrm{cm}^{-1}\right)$ : 2930, $2846\left(\mathrm{CH}_{2}\right.$ stretching), $1612(\mathrm{C}=\mathrm{N})$, $1552\left(\mathrm{NO}_{2}\right), 1360\left(\mathrm{NO}_{2}\right) .{ }^{1} \mathrm{H}$ NMR $\left(500 \mathrm{MHz}, \mathrm{CDCl}_{3}\right) \delta 8.70(\mathrm{~s}, 1 \mathrm{H}, \mathrm{CH}=\mathrm{N}), 8.49(\mathrm{~m}, 1 \mathrm{H}$, Ar-H), 8.20 (m, 1H, Ar-H), 7.68 (m, 1H, Ar-H), 7.23 (m, 2H, Ar-H), 6.98 (m, 2H, Ar-H), 4.04-3.92 (m, 2H, OCH $), 1.75\left(\mathrm{~m}, 2 \mathrm{H}, \mathrm{CH}_{2}\right), 1.44-1.30\left(\mathrm{~m}, 10 \mathrm{H}, 5 \mathrm{CH}_{2}\right), 0.96-0.88(\mathrm{~m}, 3 \mathrm{H}$, $\mathrm{CH}_{3}$ ). Elemental analyses: Found (calculated): C, 67.72 (67.56); H, 6.77 (6.65); N, 7.52 (7.43).

\section{N-(4-fluoro-3-nitrobenzylidene)-4-(hexadecyloxy)aniline, II16}

Yield: $95.8 \%$; $\mathrm{mp} 75.0^{\circ} \mathrm{C}$, FT-IR $\left(\dot{v}, \mathrm{~cm}^{-1}\right): 2925,2848\left(\mathrm{CH}_{2}\right.$ stretching $), 1615(\mathrm{C}=\mathrm{N})$, $1550\left(\mathrm{NO}_{2}\right), 1362\left(\mathrm{NO}_{2}\right) .{ }^{1} \mathrm{H}$ NMR $\left(500 \mathrm{MHz}, \mathrm{CDCl}_{3}\right) \delta 9.85(\mathrm{~s}, 1 \mathrm{H}, \mathrm{CH}=\mathrm{N}), 8.50(\mathrm{~s}, 1 \mathrm{H}$, Ar-H), 8.23-8.15 (m, 1H, Ar-H), 7.39 (t, J = 9.4 Hz, 1H, Ar-H), 7.30-7.16 (m, 2H, Ar-H associated with the solvent peak), $6.96(\mathrm{~m}, 2 \mathrm{H}, \mathrm{Ar}-\mathrm{H}) .4 .01-3.95(\mathrm{~m}, J=7.3,5.4 \mathrm{~Hz}, 2 \mathrm{H}$, $\left.\mathrm{OCH}_{2}\right), 1.85-1.75\left(\mathrm{~m}, \mathrm{~J}=16.7,9.9 \mathrm{~Hz}, 2 \mathrm{H}, \mathrm{CH}_{2}\right), 1.51-1.42\left(\mathrm{~m}, \mathrm{~J}=5.2 \mathrm{~Hz}, 2 \mathrm{H}, \mathrm{CH}_{2}\right), 1.39-1.20$ $\left(\mathrm{m}, J=47.2 \mathrm{~Hz}, 24 \mathrm{H}, 12 \mathrm{CH}_{2}\right), 0.88\left(\mathrm{t}, J=6.5 \mathrm{~Hz}, 3 \mathrm{H}, \mathrm{CH}_{3}\right) .{ }^{13} \mathrm{C} \mathrm{NMR}\left(126 \mathrm{MHz} \mathrm{CDCl}_{3}\right) \delta$ $188.87,158.81,153.18,134.62,133.82,132.04,127.49,127.25,126.07,122.56,122.25,119.13$, 116.54, 115.86, 115.74, 115.18, $68.42\left(\mathrm{OCH}_{2}\right), 32.04\left(\mathrm{CH}_{2}\right), 29.81\left(\mathrm{CH}_{2}\right), 29.77\left(\mathrm{CH}_{2}\right), 29.71$ $\left(\mathrm{CH}_{2}\right), 29.68\left(\mathrm{CH}_{2}\right), 29.52\left(\mathrm{CH}_{2}\right), 29.48\left(\mathrm{CH}_{2}\right), 29.37\left(\mathrm{CH}_{2}\right), 29.31\left(\mathrm{CH}_{2}\right), 26.15\left(\mathrm{CH}_{2}\right), 22.81$ $\left(\mathrm{CH}_{2}\right), 14.25\left(\mathrm{CH}_{3}\right)$. Elemental analyses: Found (calculated): C, 71.86 (71.87); H, 8.50 (8.53); $\mathrm{N}, 5.75$ (5.78).

\section{Conclusions}

The new two-rings azomethine series, N-4-florobenzylidene-4-(alkoxy)benzenamine (In) and N-(4-fluoro-3-nitrobenzylidene)-4-(alkyloxy)aniline (II $n$ ) were synthesized and characterized by experimental and theoretical approaches. The molecular structures were elucidated via elemental analyses, FT-IR, and NMR spectroscopy. Experimental characterizations of their mesomorphic behaviors were conducted by DSC and POM. The theoretical simulation of geometrical structure investigations were carried out by the DFT calculation method.

The study revealed that: 
1. All compounds of the synthesized laterally neat group ( $\mathbf{I} n)$ were mesomorphic, exhibiting liquid crystalline mesophases monotropically.

2. The observed smectic A phase in group $\mathbf{I} n$ covered all lengths of terminal alkoxy chains.

3. The compounds in group II $n$ were non-mesomorphic, which attributed to the steric hindrance of the large size of the nitro group, which disrupted the SmA phase.

4. The molecular geometries of the investigated compounds were highly impacted by the electronic nature, location, and size of the attached $\mathrm{NO}_{2}$ substituent.

5. The high dipole moment and steric hindrance of the $\mathrm{NO}_{2}$ moiety explain their nonmesomorphic properties.

6. The electronic and geometric structures of the nitro group through intermolecular interactions have an essential role that affects the thermal and physical properties of the present investigated compounds.

Supplementary Materials: The following are available online. Figure S1: DSC thermograms of I6 derivative upon second heating/cooling scan with a rate of $10^{\circ} \mathrm{C} / \mathrm{min}$. Figure S2: DSC thermograms of I16 derivative upon second heating/cooling scan with a rate of $10^{\circ} \mathrm{C} / \mathrm{min}$. Figure S3: DSC thermograms of II 6 derivative upon second heating/cooling scan with a rate of $10^{\circ} \mathrm{C} / \mathrm{min}$. Figure S4: DSC thermograms of II8 derivative upon second heating/cooling scan with a rate of $10^{\circ} \mathrm{C} / \mathrm{min}$.

Author Contributions: Formal analysis, M.A.E.-a., H.A.A., and S.A.A.-Z.; Funding acquisition, M.A.E.-a., H.A.A., and S.A.A.-Z.; Methodology, M.A.E.-a. and H.A.A.; Project administration, M.A.E.-a. and H.A.A.; Resources, M.A.E.-a. and S.A.A.-Z.; Software, M.A.E.-a.; Writing—original draft, M.A.E.-a., H.A.A., S.A.A.-Z., and M.M.N.; Writing-review and editing, M.A.E.-a. and H.A.A. All the authors approved the final version. All authors have read and agreed to the published version of the manuscript.

Funding: This research received no external funding.

Institutional Review Board Statement: Not applicable.

Informed Consent Statement: Not applicable.

Conflicts of Interest: The authors declare no conflict of interest.

Sample Availability: Samples of the compounds I $n, \mathbf{I I} n$ are available from the authors.

\section{References}

1. Reyes, C.G.; Sharma, A.; Lagerwall, J.P. Non-electronic gas sensors from electrospun mats of liquid crystal core fibres for detecting volatile organic compounds at room temperature. Liq. Cryst. 2016, 43, 1986-2001. [CrossRef]

2. Setia, S.; Sidiq, S.; De, J.; Pani, I.; Pal, S.K. Applications of liquid crystals in biosensing and organic light-emitting devices: Future aspects. Liq. Cryst. 2016, 43, 2009-2050. [CrossRef]

3. Gupta, R.; Manjuladevi, V.; Karthik, C.; Choudhary, K. Thin films of discotic liquid crystals and their applications. Liq. Cryst. 2016, 43, 2079-2091. [CrossRef]

4. Imrie, C.T.; Henderson, P.A.; Yeap, G.-Y. Liquid crystal oligomers: Going beyond dimers. Liq. Cryst. 2009, 36, 755-777. [CrossRef]

5. Yeap, G.-Y.; Lee, H.-C.; Mahmood, W.A.K.; Imrie, C.T.; Takeuchi, D.; Osakada, K. Synthesis, thermal and optical behaviour of non-symmetric liquid crystal dimers $\alpha$-(4-benzylidene-substituted-aniline-4'-oxy)- $\omega$-[pentyl-4-(4'-phenyl) benzoateoxy] hexane. Ph. Transit. 2011, 84, 29-37. [CrossRef]

6. Yeap, G.-Y.; Osman, F.; Imrie, C.T. Non-symmetric dimers: Effects of varying the mesogenic linking unit and terminal substituent. Liq. Cryst. 2015, 42, 543-554. [CrossRef]

7. Yeap, G.-Y.; Hng, T.-C.; Yeap, S.-Y.; Gorecka, E.; Ito, M.M.; Ueno, K.; Okamoto, M.; Mahmood, W.A.K.; Imrie, C.T. Why do non-symmetric dimers intercalate? The synthesis and characterisation of the $\alpha$-(4-benzylidene-substituted-aniline- $4^{\prime}$-oxy)- $\omega-(2-$ methylbutyl-4'-(4 "-phenyl) benzoateoxy) alkanes. Liq. Cryst. 2009, 36, 1431-1441. [CrossRef]

8. Hagar, M.; Ahmed, H.A.; Alhaddad, O.A. Experimental and theoretical approaches of molecular geometry and mesophase behaviour relationship of laterally substituted azopyridines. Liq. Cryst. 2019, 46, 1440-1451. [CrossRef]

9. Hagar, M.; Ahmed, H.A.; Saad, G.R. Mesophase stability of new Schiff base ester liquid crystals with different polar substituents. Liq. Cryst. 2018, 45, 1324-1332. [CrossRef]

10. Ahmed, H.; Hagar, M.; Saad, G. Impact of the proportionation of dialkoxy chain length on the mesophase behaviour of Schiff base/ester liquid crystals; experimental and theoretical study. Liq. Cryst. 2019, 46, 1611-1620. [CrossRef]

11. Hagar, M.; Ahmed, H.; Saad, G. Synthesis and mesophase behaviour of Schiff base/ester 4-(arylideneamino) phenyl-4 "-alkoxy benzoates and their binary mixtures. J. Mol. Liq. 2019, 273, 266-273. [CrossRef] 
12. Ahmed, H.; Hagar, M.; El-Sayed, T.; Alnoman, R.B. Schiff base/ester liquid crystals with different lateral substituents: Mesophase behaviour and DFT calculations. Liq. Cryst. 2019, 46, 1-11. [CrossRef]

13. Ahmed, H.; Hagar, M.; Alhaddad, O. New chair shaped supramolecular complexes-based aryl nicotinate derivative; mesomorphic properties and DFT molecular geometry. RSC Adv. 2019, 9, 16366-16374. [CrossRef]

14. Hagar, M.; Ahmed, H.; Alhaddad, O. New azobenzene-based natural fatty acid liquid crystals with low melting point: Synthesis, DFT calculations and binary mixtures. Liq. Cryst. 2019, 46, 2223-2234. [CrossRef]

15. Hagar, M.; Ahmed, H.; El-Sayed, T.; Alnoman, R. Mesophase behavior and DFT conformational analysis of new symmetrical diester chalcone liquid crystals. J. Mol. Liq. 2019, 285, 96-105. [CrossRef]

16. Hammett, L.P. Physical Organic Chemistry, 1st ed.; Wiley Online Library: New York, NY, USA, 1940.

17. MarekáKrygowski, T. The nitro group as substituent. Chem. Soc. Rev. 1996, 25, 71-75.

18. Irle, S.; Krygowski, T.; Niu, J.; Schwarz, W. Substituent Effects of-NO and-NO2, Groups in Aromatic Systems. J. Org. Chem. 1995, 60, 6744-6755. [CrossRef]

19. Yumatov, V.D.; Murakhtanov, V.; Salakhutdinov, N.; Okotrub, A.; Mazalov, L.; Logunova, L.; Koptyug, V.; Furin, G. Electronic structure of molecules of substituted benzenes by X-ray spectroscopy. I. Nitrobenzene. J. Struct. Chem. 1988, 28, 696-703. [CrossRef]

20. Domenicano, A.; Schultz, G.; Hargittai, I.; Colapietro, M.; Portalone, G.; George, P.; Bock, C.W. Molecular structure of nitrobenzene in the planar and orthogonal conformations. J. Struct. Chem. 1990, 1, 107-122. [CrossRef]

21. Boese, R.; Bläser, D.; Nussbaumer, M.; Krygowski, T.M. Low temperature crystal and molecular structure of nitrobenzene. J. Struct. Chem. 1992, 3, 363-368. [CrossRef]

22. Politzer, P.; Lane, P.; Jayasuriya, K.; Domelsmith, L.N. Examination of some effects of NO2 rotation in nitrobenzene. J. Am. Chem. Soc. 1987, 109, 1899-1901. [CrossRef]

23. Ritchie, J.P. A look at mesomerism in nitrobenzene. Tetrahedron 1988, 44, 7465-7478. [CrossRef]

24. Gill, P.M.; Head-Gordon, M.; Pople, J.A. Efficient computation of two-electron-repulsion integrals and their nth-order derivatives using contracted Gaussian basis sets. J. Phys. Chem. 1990, 94, 5564-5572. [CrossRef]

25. Minkin, V.I. Dipole Moments in Organic Chemistry; Springer Science \& Business Media: Berlin, Germany, 2012.

26. Fraser, R.R.; Ragauskas, A.J.; Stothers, J. Nitrobenzene valence bond structures: Evidence in support of through-resonance from oxygen-17 shieldings. J. Am. Chem. Soc. 1982, 104, 6475-6476. [CrossRef]

27. Craik, D.J.; Levy, G.C.; Brownlee, R.T. Substituent effects on nitrogen-15 and oxygen-17 chemical shifts in nitrobenzenes: Correlations with electron densities. J. Org. Chem. 1983, 48, 1601-1606. [CrossRef]

28. Petrov, V.F.; Shimizu, Y. Nitro substitution in achiral calamitic liquid crystals. Liq. Cryst. 2001, 28, 1627-1647. [CrossRef]

29. Hird, M.; Toyne, K.J.; Goodby, J.W.; Gray, G.W.; Minter, V.; Tuffin, R.P.; McDonnell, D.G. Synthesis, mesomorphic behaviour and optical anisotropy of some novel materials for nematic mixtures of high birefringence. J. Mater. Chem. 2004, 14, 1731-1743. [CrossRef]

30. Da Rosa, R.R.; Tariq, M.; Weber, C.S.; Hameed, S.; Silva, S.; Merlo, A.A. Hybrid liquid crystals tetrazolyl and isoxazolyl cinnamates. Liq. Cryst. 2016, 43, 1659-1670. [CrossRef]

31. Chen, B.-Q.; Wen, J.-X. Synthesis and mesophase behaviour of mesogens bearing omega, alpha, alpha-trihydroperfluoroalkoxy end tails. Liq. Cryst. 1999, 26, 1135-1140. [CrossRef]

32. Nafee, S.S.; Hagar, M.; Ahmed, H.A.; Alhaddad, O.; El-Shishtawy, R.M.; Raffah, B.M. New two rings Schiff base liquid crystals; ball mill synthesis, mesomorphic, Hammett and DFT studies. J. Mol. Liq. 2020, 299, 112161. [CrossRef]

33. Ahmed, N.H.; Saad, G.R.; Ahmed, H.A.; Hagar, M. New wide-stability four-ring azo/ester/Schiff base liquid crystals: Synthesis, mesomorphic, photophysical, and DFT approaches. RSC Adv. 2020, 10, 9643-9656. [CrossRef]

34. Ahmed, H.; Hagar, M.; Alhaddad, O. Mesomorphic and geometrical orientation study of the relative position of fluorine atom in some thermotropic liquid crystal systems. Liq. Cryst. 2020, 47, 404-413. [CrossRef]

35. Alnoman, R.B.; Hagar, M.; Ahmed, H.A.; Naoum, M.M.; Sobaih, H.A.; Almshaly, J.S.; Haddad, M.M.; Alhaisoni, R.A.; Alsobhi, T.A. Binary Liquid Crystal Mixtures Based on Schiff Base Derivatives with Oriented Lateral Substituents. Crystals 2020, 10, 319. [CrossRef]

36. Nafee, S.S.; Ahmed, H.; Hagar, M. Theoretical, experimental and optical study of new thiophene-based liquid crystals and their positional isomers. Liq. Cryst. 2020, 47, 1291-1302. [CrossRef]

37. Kelker, H.; Scheurle, B. Eine flüssig-kristalline (nematische) Phase mit besonders niedrigem Erstarrungspunkt. Angew. Chem. 1969, 81, 903-904. [CrossRef]

38. Nesrullajev, A.; Bilgin-Eran, B. Mesomorphic, morphologic and thermotropic properties of 4-hexyl-N-(4-hexadecyloxysalicylidene) aniline. Mater. Chem. Phys. 2005, 93, 21-25. [CrossRef]

39. Yasa-Sahin, O.; Yazici, O.; Karaagac, B.; Sakar, D.; Cankurtaran, O.; Bilgin-Eran, B.; Karaman, F. A new liquid crystal of considerable value for the separation of closely related solvents by gas chromatography. Liq. Cryst. 2010, 37, 1111-1118. [CrossRef]

40. Canli, N.Y.; Günes, S.; Pivrikas, A.; Fuchsbauer, A.; Sinwel, D.; Sariciftci, N.; Yasa, Ö.; Bilgin-Eran, B. Chiral (S)-5-octyloxy-2-[\{4(2-methylbuthoxy)-phenylimino\}-methyl]-phenol liquid crystalline compound as additive into polymer solar cells. Sol. Energy Mater. Sol. Cells 2010, 94, 1089-1099. [CrossRef] 
41. Ge, L.-N.; Xian, S.-W.; Huang, Y.; Min, Y.; Lv, J.-M.; Tian, M.; Yao, D.-S. Synthesis and mesomorphism of novel multi-arm liquid crystals with cholic acid as chiral centre linking Schiff base moieties as mesogens. Liq. Cryst. 2017, 45, 1055-1067. [CrossRef]

42. Huang, C.-C.; Chen, Y.-H.; Chen, S.-Y.; Sun, Y.-Z.; Wu, Z.-Y.; Yu, M.-C.; Chen, B.-H.; Hsu, I.-J.; Wu, L.-C.; Lee, J.-J. Broad temperature range of cubic blue phase present in simple binary mixture systems containing rodlike Schiff base mesogens with tolane moiety. Soft Matter 2016, 12, 3110-3120. [CrossRef]

43. Veerabhadraswamy, B.N.; Rao, D.S.S.; Yelamaggad, C.V. Ferroelectric Liquid Crystals: Synthesis and Thermal Behavior of Optically Active, Three-Ring Schiff Bases and Salicylaldimines. Chem. Asian J. 2018, 13, 1012-1023. [CrossRef]

44. Dubey, R.; Yerrasani, R.; Karunakar, M.; Singh, A.K.; Kumar, S.; Rao, T. Synthesis, structural and mesophase characterization of isoindoline-1, 3-dione based mesogenic Schiff bases. J. Mol. Liq. 2018, 251, 142-149. [CrossRef]

45. Lei, Z.-Y.; Lee, G.-H.; Lai, C.K. Luminescent mesogenic borondifluoride complexes with the Schiff bases containing salicylideneamines and $\beta$-enaminoketones core systems. J. Mol. Liq. 2018, 260, 44-56. [CrossRef]

46. Nagaveni, N.; Roy, A.; Prasad, V. Achiral bent-core azo compounds: Effect of different types of linkage groups and their direction of linking on liquid crystalline properties. J. Mater. Chem. 2012, 22, 8948-8959. [CrossRef]

47. Ahmed, H.; Mansour, E.; Hagar, M. Mesomorphic study and DFT simulation of calamitic Schiff base liquid crystals with electronically different terminal groups and their binary mixtures. Liq. Cryst. 2020, 47, 2292-2304. [CrossRef]

48. Hagar, M.; Ahmed, H.; Alhaddadd, O. DFT Calculations and Mesophase Study of Coumarin Esters and Its Azoesters. Crystals 2018, 8, 359. [CrossRef]

49. Hagar, M.; Soliman, S.M.; Ibid, F.; El Sayed, H. Quinazolin-4-yl-sulfanylacetyl-hydrazone derivatives; Synthesis, molecular structure and electronic properties. J. Mol. Struct. 2013, 1049, 177-188. [CrossRef]

50. Soliman, S.M.; Hagar, M.; Ibid, F.; El Sayed, H. Experimental and theoretical spectroscopic studies, HOMO-LUMO, NBO analyses and thione-thiol tautomerism of a new hybrid of 1,3,4-oxadiazole-thione with quinazolin-4-one. Spectrochim. Acta A Mol. Biol. Spectrosc. 2015, 145, 270-279. [CrossRef]

51. Hagar, M.; Soliman, S.M.; Ibid, F.; El Sayed, H. Synthesis, molecular structure and spectroscopic studies of some new quinazolin-4 $(3 \mathrm{H})$-one derivatives; an account on the N-versus S-Alkylation. J. Mol. Struct. 2016, 1108, 667-679. [CrossRef]

52. Aboelnaga, A.; Hagar, M.; Soliman, S.M. Ultrasonic Synthesis, Molecular Structure and Mechanistic Study of 1, 3-Dipolar Cycloaddition Reaction of 1-Alkynylpyridinium-3-olate and Acetylene Derivatives. Molecules 2016, 21, 848. [CrossRef] [PubMed]

53. Galewski, Z. Liquid-crystalline properties of 4-halogenobenzylidene-4'-alkoxy-anilines. In Proceedings of Liquid and Solid State Crystals: Physics. Technol. Appl. 1992, 1845, 452-458.

54. Naoum, M.M.; Metwally, N.H.; Abd Eltawab, M.M.; Ahmed, H.A. Polarity and steric effect of the lateral substituent on the mesophase behaviour of some newly prepared liquid crystals. Liq. Cryst. 2015, 42, 1351-1369. [CrossRef]

55. Frisch, M.J.; Trucks, G.W.; Schlegel, H.B.; Scuseria, G.E.; Robb, M.A.; Cheeseman, J.R.; Scalmani, G.; Barone, V.; Mennucci, B.; Petersson, G.A.; et al. Gaussian 09, Revision A. 01; Gaussian Inc.: Wallingford, CT, USA, 2009.

56. Elshakre, M.E.; Alalawy, H.H.; Awad, M.I.; El-Anadouli, B.E. On the role of the electronic states of corrosion inhibitors: Quantum chemical-electrochemical correlation study on urea derivatives. Corros. Sci. 2017, 124, 121-130. [CrossRef]

57. Naoum, M.M.; Fahmi, A.A.; Ahmed, N.H.; Saad, G.R. The effect of lateral methyl substitution on the mesophase behaviour of aryl 4-alkoxyphenylazo benzoates. Liq. Cryst. 2015, 42, 1627-1637. [CrossRef]

58. Thaker, B.; Kanojiya, J.; Tandel, R. Effects of different terminal substituents on the mesomorphic behavior of some azo-schiff base and azo-ester-based liquid crystals. Mol. Cryst. Liq. Cryst. 2010, 528, 120-137. [CrossRef]

59. Khoo, I.-C.; Wu, S.-T. Optics and Nonlinear Optics of Crystals; World Scientific: Singapore, 1993.

60. Chemla, D.S. Nonlinear Optical Properties of Organic Molecules and Crystals; Elsevier: New York, NY, USA, 2012 ; Volume 1.

61. Ahmed, H.A.; Hagar, M.; Alhaddad, O.A. Phase behavior and DFT calculations of laterally methyl supramolecular hydrogenbonding complexes. Crystals 2019, 9, 133. [CrossRef] 